\title{
Multi-Variable Location Assessment for Building Modified Stone- Concrete Dams in the Drainage Basin of Golpayegan Through Fuzzy Logic and Boolean Method, Isfahan, Iran
}

\author{
ZahraGhasem ${ }^{1}$, Mojtaba Pirnazar ${ }^{2}$, Kaveh Ostad-Ali-Askari ${ }^{3 *}$, Saeid Eslamian ${ }^{4}$, Mohsen \\ Ghane $^{5}$, Vijay P. Singh ${ }^{6}$, Nicolas R. Dalezios ${ }^{7}$, Shahide Dehghan ${ }^{8}$, Neda Taghipour ${ }^{9}$, \\ Maryam Marani-Barzani ${ }^{10}$ \\ ${ }^{1}$ Department of Remote Sensing, Maybod Branch, Islamic Azad University, Iran \\ ${ }^{2}$ Department of Remote Sensing, Tabriz University, Tabriz, Iran \\ 3* Department of Civil Engineering, Isfahan (Khorasgan) Branch, Islamic Azad University, Isfahan, Iran \\ ${ }^{4}$ Department of Water Engineering, Isfahan University of Technology, Isfahan, Iran \\ ${ }^{5}$ Civil Engineering Department, South Tehran Branch, Islamic Azad University, Tehran, Iran \\ ${ }^{6}$ Department of Biological and Agricultural Engineering \&Zachry Department of Civil Engineering, Texas A \\ and M University, 321 Scoates Hall, 2117 TAMU, College Station, Texas 77843-2117, U.S.A. \\ ${ }^{7}$ Laboratory of Hydrology, Department of Civil Engineering, University of Thessaly, Volos, Greece \& \\ Department of Natural Resources Development and Agricultural Engineering, Agricultural University of \\ Athens, Athens, Greece. \\ ${ }^{8}$ Department of Geography, Najafabad Branch, Islamic Azad University, Najafabad, Iran \\ ${ }^{9}$ Department of Urban Engineering, Isfahan (Khorasgan) Branch, Islamic Azad University, Isfahan, Iran \\ ${ }^{10}$ Department of Geography, University of Malaya (UM) ,50603 Kuala Lumpur, Malaysia
}

*Corresponding Author: Dr. Kaveh Ostad-Ali-Askari, Department of Civil Engineering, Isfahan (Khorasgan) Branch, Islamic Azad University, Isfahan, Iran.Emails: Koa.askari@khuisf.ac.ir, Kaveh.oaa2000@gmail.com

\begin{abstract}
Water and soil are the most important natural resources, which have a major role in the establishment and survival of human civilization. For this matter, studying water and soil resources is significantly important. These resources have been damaged by human interference, which can be problematic for the continuation of human lives. The aim of this study is to investigate an appropriate location for creating a modified dam along canals in order to reduce erosion and sedimentation and their damaging effects. In this research, the intended layers were prepared in the ARC GIS software. In a tree model prepared in ILWIS, the geographical and economic factors and limitations were taken into consideration. The map of the factors and limitations was standardized. The weight of each layer was given through the Fuzzy Logic and Boolean method accordant with a, expert's opinion. At last, by integrating the layers of the final map in which the geographical priorities for building a stone-concrete dam along the canal are displayed. The results show that the SMCE method is best for a location.
\end{abstract}

Keywords: modified dams, geographical multi-variable assessment, Golpayegan, stone-concrete dam

\section{INTRODUCTION}

Two of the dangers that threatens water and soil resources, are erosion and sedimentation. Erosion, as an environmental destruction factor, in addition to destroying the soil and reducing lands' soil fertility, it also pollutes surface water sources and reduces water penetration in soil, which leads to destruction of rangelands and forest lands, decrease in vegetation, reduction in recharge of groundwater sources and expedition of desertification. Pollutants that accumulate along with deposits, especially fine deposits in reservoirs of dams, lakes, wetlands and riverbeds, are considered as future danger. [1] One of the simple methods for controlling floodwater and reducing flood damages in the 
canals of drainage basins, is building modified dams. Most check dams are filled with coarse-grained and colluvial deposits, which the chance of the reaching the back of downstream dams is very low; therefore, it seemed necessary to study the performance of these structures in keeping these fine deposits [4]. Modified dams or sedimentation dams are small structures that by reducing the waterways' slope and decreasing the water flow, they inhibit sedimentation and reduce erosion in waterways, [3] and then lead to modifying the longitudinal profiles of waterways; thus, these type of structures are known as modified dams [1]. These structures are considered as one of the major tools in watershed activities for protecting water and soil; which during the recent years they have been used on a very extensive level by executive authorities, and have dedicated a major sum of these expenses to itself; however, despite all efforts and investments in this sector, the main problems, meaning erosion and destruction of natural resources are still increasing. Considering the desert evidence and conducted studies on downstream, investigating the type and gradation of deposits and the manner of which they are transferred to water, can determine their level of effectiveness on reducing deposits that are finally transferred to the reservoir of reservoir dams and can be a guide for selecting the place for check dams [3]. Since waterway No. 3 and 4 under study for the location of the check dams, stone-concrete dams were found to be more appropriate. Golpayegan is a mountainous region. The Golpayegan'splain is extensive and its water is supplied by rivers, qanats, springs and other groundwater resources. Iran's central mountain range goes through this county. From those who have conducted studies in the field of modified dams, Ismael Namghi and his colleagues can be mentioned, whom studied the dry-stack in the Doroodzan Dam. The reason for the inappropriate choice of gradient limit are the upstream-modified dams buried in the deposits in the downstreammodified dams. If the distance of modified dams were selected based on the gradient limit, it would have led to reducing the cost of building modified dams. Ghazavi and colleagues also conducted a study on the effect of modified dams on the waterway morphology and sediment of deposits in the drainage basin of Javan-Fars. In their study, they found that the performance of the modified dams in different parts throughout the waterway is more for trapping fine deposits in the end than the springhead. Xiang Chou and colleagues in their study on the Yellow River, they found that the modified dams were the most effective method for rapid reduction of coarse-grained deposits that had entered the Yellow River. In the hot and dry weather and infertile soil of alluvial plain in China, Goul and colleagues found that the order of modified dams in the gutter are the most effective way to protect the soil. Marston and Doulan showed that building modified dams in this region were not effective.

\section{UNDER-STUDY REGION}

Golpayegan is located from north to KhomeinKomreh and small part of its west to Bakhtiyari and Aligodarz mountains and from south to Khansar and Bakhtiyari mountains and from east to Meymeh and Sheikh Ahmad Mountain and SorkhMountain and Prophet Saleh Mountain and MahvarGolgaleh and from southeast to Najafabad. It is 1818 meters above sea level (base height $=$ average water level of the Persian Golf in the Fav region that is the base for European regions). Golpayegan's climate is variable and has cold winters with a minimum temperature of $21^{\circ}$ degrees and has hot and dry summers, which its maximum temperature reaches +37.5 degrees centigrade. This region has a longitude of $33^{\circ} 02^{\prime} 03^{\prime \prime}$ and latitude $50^{\circ} 20^{\prime} 17^{\prime \prime} \mathrm{W}$. Rainfall often occurs in winter and about $300 \mathrm{~mm}$. Gopayegan is a mountainous region.

Based on the census of year 2006, the population of Golpayegan was 86601 (24820 households). This county is consisted of three rural districts (plain, riverside and Nivan), three cities (Golpayegan, Goged and Golshahr), and 54 villages. The present villages in this county include Dareh Bid, Doshakhrat and Ghale Baba Mohammad.The altitudes of Golpayegan county that have been separated from the eastern trail of Zagros mountain range and often from the mountains surrounding Isfahan, belongs to the second geologic period and they extends from northwest towards southeast as several parallel chains. The highest summit of this county is Prophet Saleh Mountain on which there is a holy shrine. The GolpayeganRiver, which originates from Zagros altitudes that is proximity of Zayandehroud River's branches, constitutes the main drainage network of the region. 


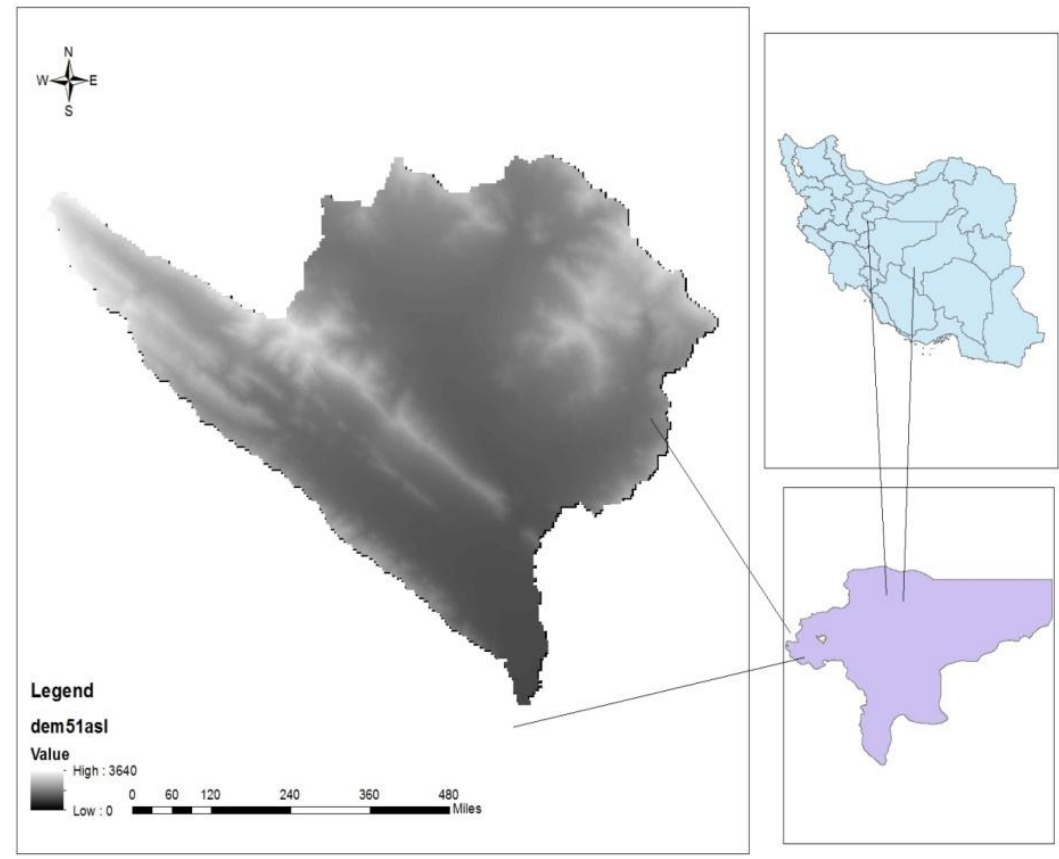

Figure1. Location of the Under Study Field

\section{MATERials \& MethodS}

In the ARCMAP software, the intended layers' coordinates were equalized. First, the layers were converted to GCS and then, were reverted to UTM. The limitations and factors maps in the tree model that were prepared in SMCE in ILWIS software (Figure 2) were standardized and weighed. Through the priorities' map, the construction of these check dams were obtained. Generally, using this type of modelling and utilizing laws of decision causes saving in time and costs and finding a more precise location. The information layers used for locating the stone-concrete modified dam are displayed in figure 3. As we see in figure 3, the limitations are weighted by the Boolean method, until the incompatible factors are eliminated and based on their level of significance for building stoneconcrete modified dam, they were placed in a factors group with a weight between zero and one. As an example, the geology of the region was weighted through the rating method. In such manner that the loose stone due to having less resistance towards erosion gets a higher rating and as the stone is harder, it gets a lower rating.

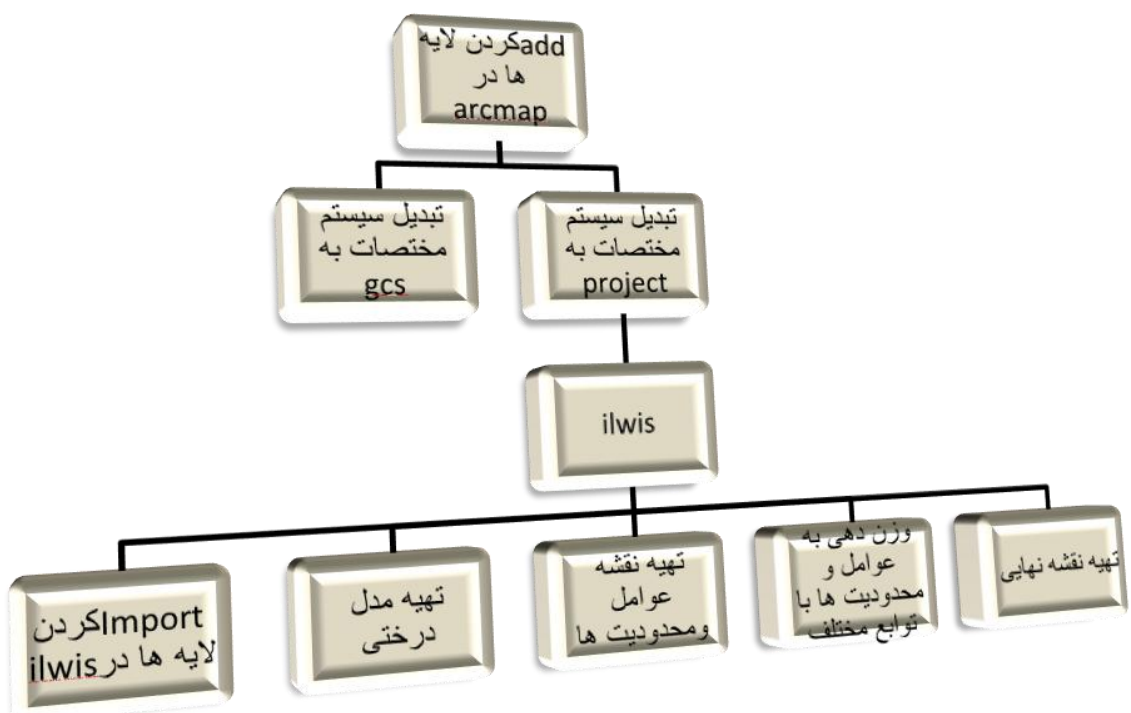

Figure2: Working phases in the ILWIS and ARCMAP software 
Multi-Variable Location Assessment for Building Modified Stone-Concrete Dams in the Drainage Basin of Golpayegan Through Fuzzy Logic and Boolean Method, Isfahan, Iran

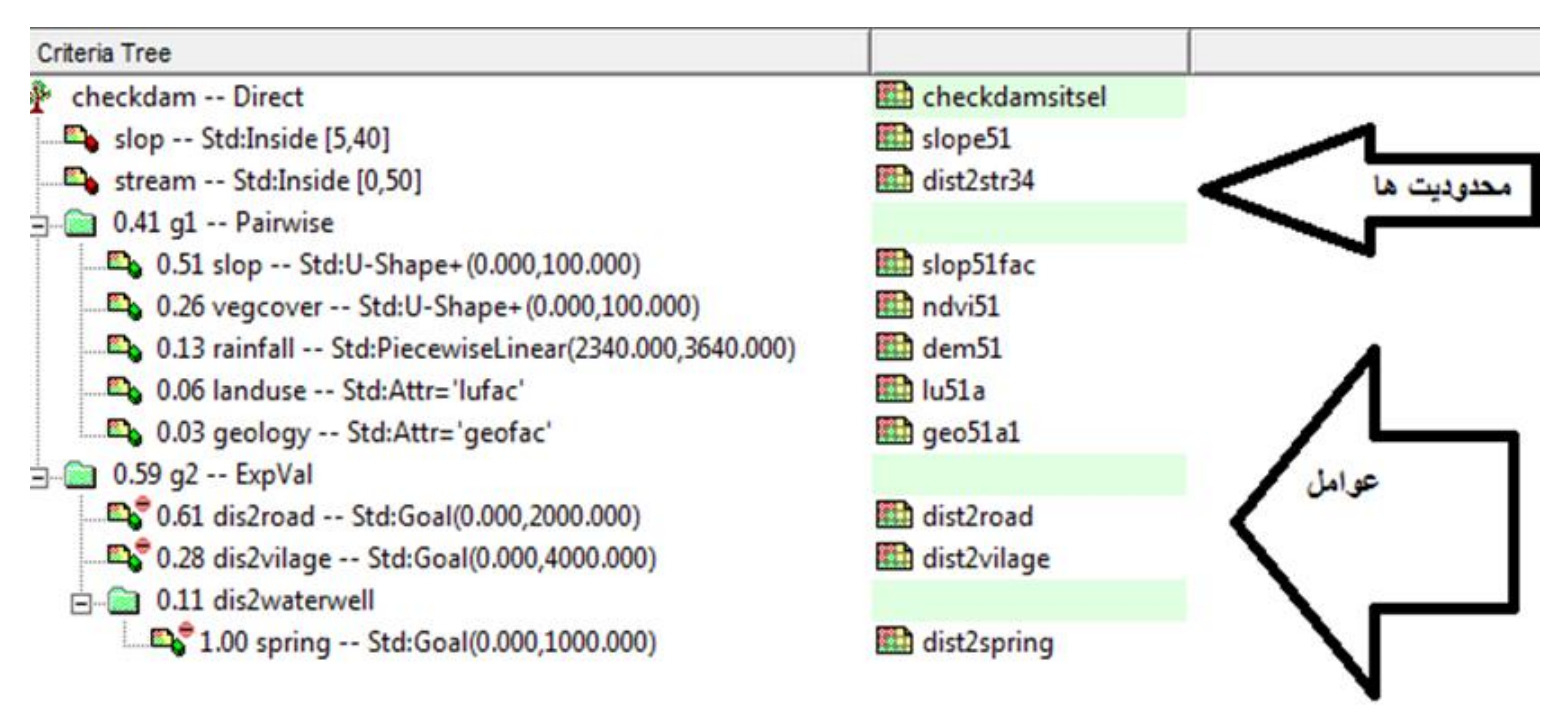

Figure3: Tree Model for Location and Economic Factors and Limitations

Table of Factors and Limitations

\begin{tabular}{|c|c|c|c|c|c|}
\hline Standard & Map & Function & Reason & Weighting & Value \\
\hline \multirow[t]{2}{*}{ Limitation } & Waterway & $\begin{array}{l}\text { Equal to the } \\
\text { considered pixel } \\
\text { size. }\end{array}$ & $\begin{array}{l}\text { Where the } \\
\text { waterway }\end{array}$ & \multirow[t]{2}{*}{$\begin{array}{l}\text { Boolean (0 and } \\
1)\end{array}$} & \\
\hline & Slope & $\begin{array}{l}\text { Boolean function } \\
\text { with a slope } \\
\text { between } 4-50 \\
\text { giving a value } \\
\text { one and the rest } \\
\text { value zero }\end{array}$ & $\begin{array}{l}\text { Medium slope } \\
\text { because of less } \\
\text { erosion and } \\
\text { precipitation is } \\
\text { from high and } \\
\text { less slope. }\end{array}$ & & \\
\hline \multirow[t]{5}{*}{ Factors } & Slope & $\begin{array}{l}\text { Standard (high } \\
\text { slope has more } \\
\text { value) }\end{array}$ & $\begin{array}{l}\text { Higher slope is } \\
\text { more appropriate } \\
\text { because of more } \\
\text { erosion }\end{array}$ & \multirow[t]{5}{*}{$\begin{array}{l}\text { Paired } \\
\text { Comparison }\end{array}$} & 0.51 \\
\hline & Geology & $\begin{array}{l}\text { Ranking (the } \\
\text { looser stone gets } \\
\text { a higher ranking } \\
\text { and the harder } \\
\text { stone gets a } \\
\text { lower ranking) }\end{array}$ & $\begin{array}{l}\text { The looser stone } \\
\text { goes through } \\
\text { more erosion }\end{array}$ & & 0.03 \\
\hline & Land Usage & Ranking & $\begin{array}{l}\text { Owned } \\
\text { properties or } \\
\text { those with } \\
\text { economic value } \\
\text { are not } \\
\text { appropriate for } \\
\text { building a dam } \\
\text { and get lower } \\
\text { ranking }\end{array}$ & & 0.06 \\
\hline & Vegetation & Ranking & $\begin{array}{l}\text { If the vegetation } \\
\text { is inappropriate, } \\
\text { there is a need to } \\
\text { create a dam } \\
\text { because erosion } \\
\text { will be more }\end{array}$ & & 0.26 \\
\hline & Precipitation & $\begin{array}{l}\text { Standard (Higher } \\
\text { altitudes due to } \\
\text { more } \\
\text { precipitation are } \\
\text { of more } \\
\text { significance) }\end{array}$ & $\begin{array}{l}\text { Precipitation } \\
\text { causes erosion to } \\
\text { increase }\end{array}$ & & 0.13 \\
\hline
\end{tabular}


Multi-Variable Location Assessment for Building Modified Stone-Concrete Dams in the Drainage Basin of Golpayegan Through Fuzzy Logic and Boolean Method, Isfahan, Iran

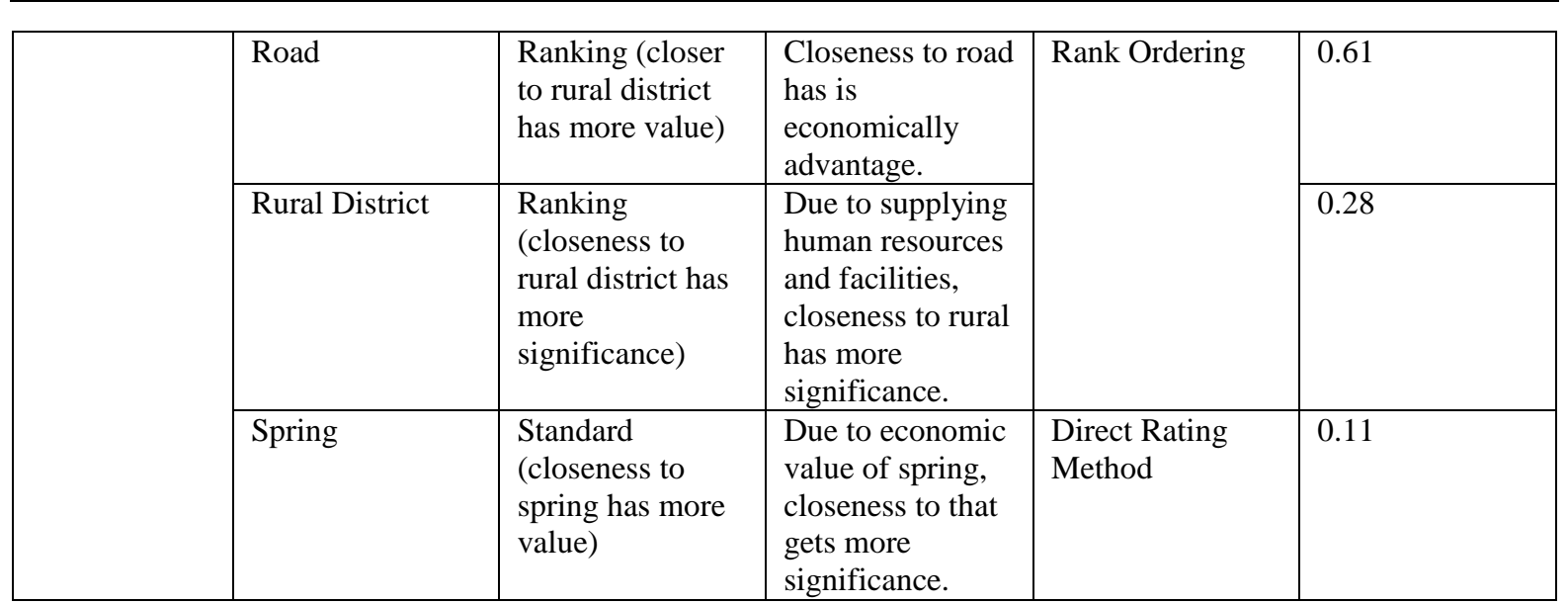
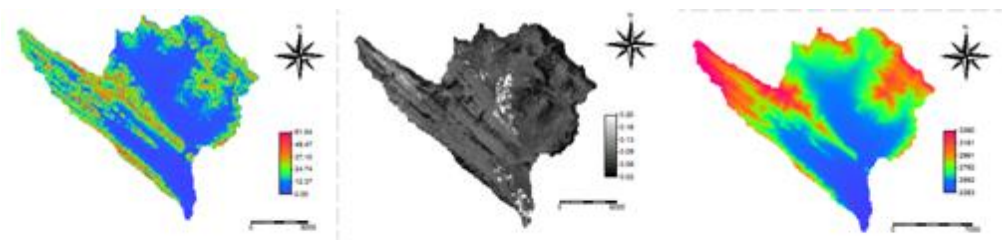

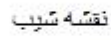

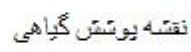

نقانتبان الرئفاع
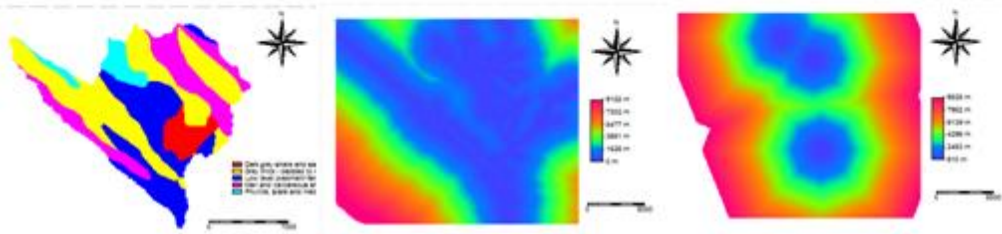

نقتسل زمين تنفنسى

نقنته جاند

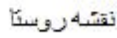

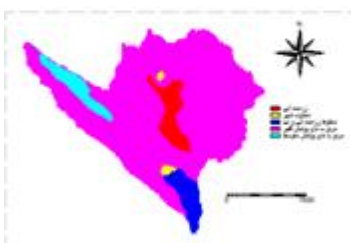

نقئه كاريزى نمين
文

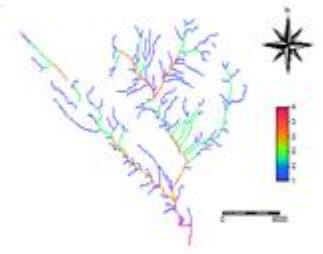

نقيته آنير اهنه

Figure4: Map of limitations and economic and location factors

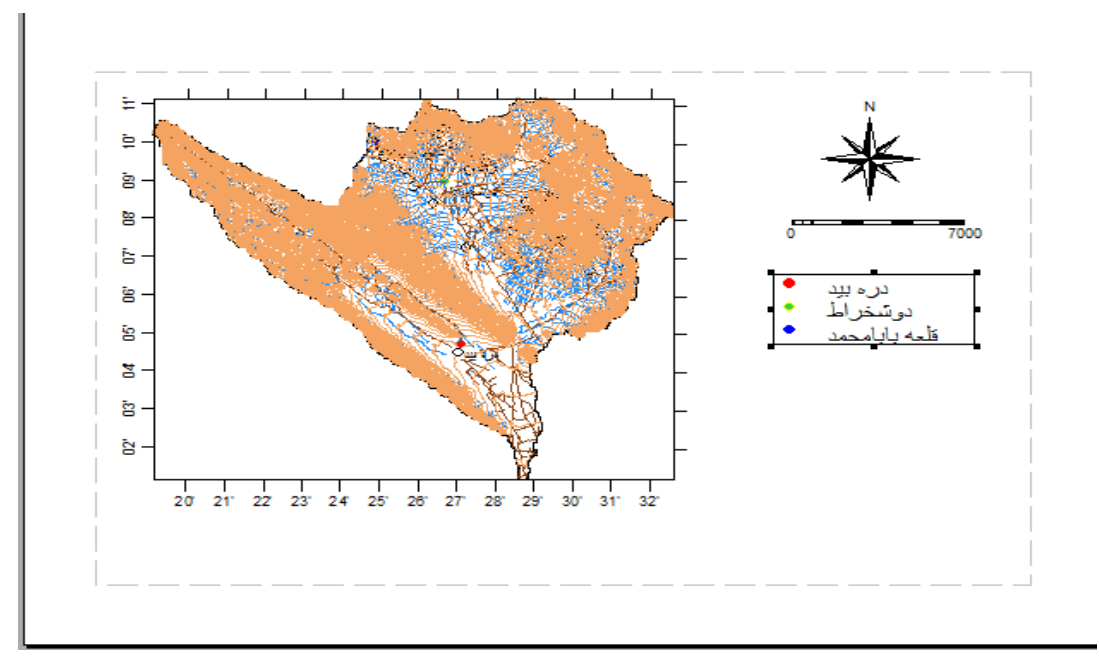

Figure5. Map of Drainage Basin 


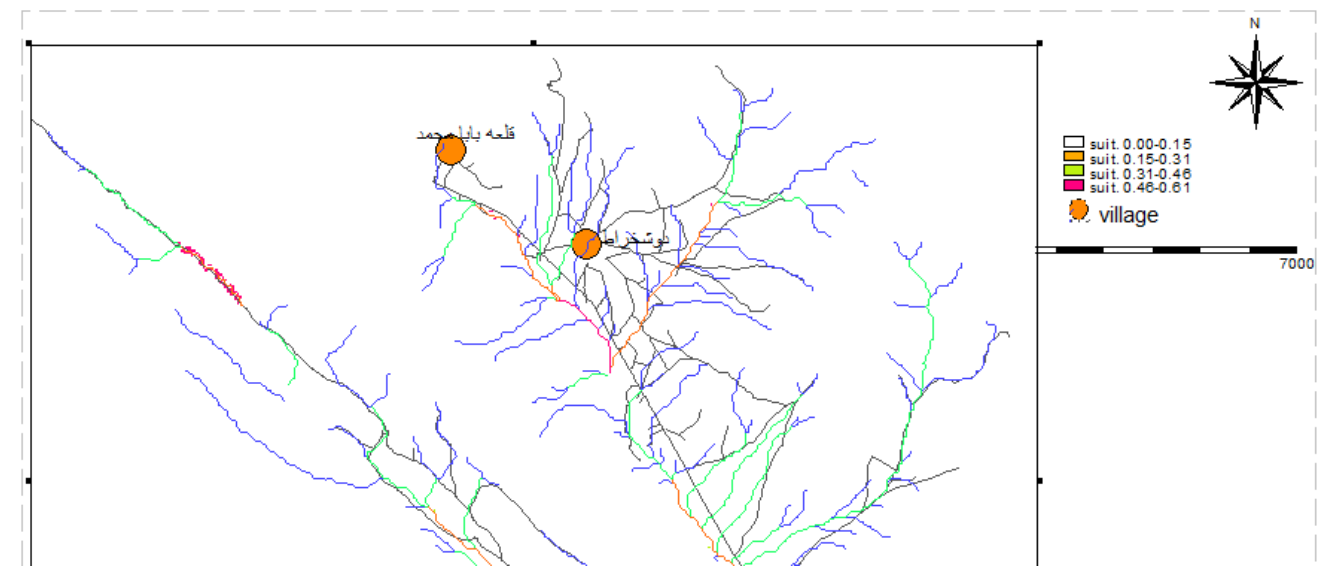

Figure6. Priority regions for building stone-concrete modified dam

\section{CONCLUSiOnS}

In this research, the priority regions for building a stone-concrete modified dam was determined (figure 5). Among those who have worked in this field, the study conducted on dry-stack dams in sedimentation of deposits in the Dom Tang Darab region, which was an indication of good performance of these dams in sedimentation of fine deposits. In another research in regards to the role of modified dams in controlling the deposits in the Taham drainage basin in Zanjan Province, which was a representation of the difference in the level of deposits in the downstream is variable. The chosen criteria were based on the expert's opinion. In the prepared tree model, economic factors such as distance from rural district and distance from road have more significance compared to natural factors. Based on the weighting and integration of factors and limitations, the priority locations for building stone-concrete dams have been specified as in figure No. 6 .

\section{REFERENCES}

[1] Ostad-Ali-Askari, K., Shayannejad, M. 2015, Study of sensitivity of Autumnal wheat to under irrigation in Shahrekord, Shahrekord City, Iran. International Journal of Agriculture and Crop Sciences, 8 (4), 602-605.

[2] Shayannejad, M., Akbari, N., Ostad-Ali-Askari, K. 2015, Study of modifications of the river physical specifications on muskingum coefficients, through employment of genetic algorithm. International Journal of Development Research, 5(3), 3782-3785.

[3] Ostad-Ali-Askari, K., Shayannejad, M. 2015, The Reviews of Einstein's Equation of Logarithmic Distribution Platform and the Process of Changes in the Speed Range of the Karkheh River, Khuzestan province, Iran. International Journal of Development Research, 5(3), 3786-3790.

[4] Ostad-Ali-Askari, K., Shayannejad, M., Ghorbanizadee-Kharazi, H. 2015, Assessment of artificial neural network performance and exponential regression in prediction of effective rainfall, International Journal of Development Research, 5(3),3791-3794.

[5] Shayannejad, M. Akbari, N. and Ostad-Ali-Askari, K. 2015, Determination of the nonlinear Muskingum model coefficients using genetic algorithm and numerical solution of the continuity. Int. J. of Science: Basic and Applied Research, 21(1),1-14.

[6] Ostad-Ali-Askari, K., Shayannejad, M. 2015, The Study of Mixture Design for Foam Bitumen and the Polymeric and Oil Materials Function in Loose Soils Consolidation. Journal of Civil Engineering Research, 5(2), 39-44. DOI: 10.5923/j.jce.20150502.04

[7] Sayedipour, M., Ostad-Ali-Askari, K., Shayannejad, M. 2015, Recovery of Run off of the Sewage Refinery, a Factor for Balancing the Isfahan-Borkhar Plain Water Table in Drought Crisis Situation in Isfahan Province-Iran. American Journal of Environmental Engineering, 5(2): 43-46. DOI: 10.5923/j.ajee.20150502.02

[8] Ostad-Ali-Askari, K., Shayannejad, M. 2015, Developing an Optimal Design Model of Furrow Irrigation Based on the Minimum Cost and Maximum Irrigation Efficiency. International Bulletin of Water Resources \& Development, 3(2), 18-23.

[9] Ostad-Ali-Askari, K., Shayannejad, M. 2015, Presenting a Mathematical Model for Estimating the Deep Percolation Due to Irrigation. International Journal of Hydraulic Engineering, 4(1), 17-21. DOI: 10.5923/j.ijhe.20150401.03. 
Multi-Variable Location Assessment for Building Modified Stone-Concrete Dams in the Drainage Basin of Golpayegan Through Fuzzy Logic and Boolean Method, Isfahan, Iran

[10] Ostad-Ali-Askari, K., Shayannejad, M. 2015, Usage of rockfill dams in the HEC-RAS software for the purpose of controlling floods. American Journal of Fluid Dynamics, 5(1), 23-29. DOI: 10.5923/j.ajfd.20150501.03.

[11] Ostad-Ali- Askari, K., Shayannejad, M. 2015, The effect of heterogeneity due to inappropriate tillage on water advance and recession in furrow irrigation. Journal of Agricultural Science, 7(6), 127-136.

[12] Shayannejad, M., Ostad-Ali-Askari, K. 2015, Effects of magnetized municipal effluent on some chemical properties of soil in furrow irrigation. International Journal of Agriculture and Crop Sciences, 8(3), 482489.

[13] Ostad-Ali-Askari, K., Shayannejad, M. 2015, Optimal design of pressurized irrigation laterals installed on sloping land. International Journal of Agriculture and Crop Sciences, ISSN 2227-670X. 8(5), 792-797.

[14] Ostad-Ali-Askari K, Shayannejad M, Eslamian S, Navab-Pour B. 2016, Comparison of solution of SaintVenant equations by characteristics and finite difference methods for unsteady flow analyzing in open channel. International Journal of Hydrology Science and Technology, 6(3), 9-18.

[15] Ostad-Ali-Askari K, Shayannejad M, Eslamian S, et al. 2017, Deficit Irrigation: Optimization Models. Management of Drought and Water Scarcity. Handbook of Drought and Water Scarcity, Taylor \& Francis Publisher, USA. Vol. 3. $1^{\text {th }}$ Edition, pp: 373-389.

[16] Eskandari S, Hoodaji M, Tahmourespour A, Abdollahi A, Mohammadian-Baghi T, Eslamian S, Ostad-AliAskari K. 2017, Bioremediation of Polycyclic Aromatic Hydrocarbons by Bacillus Licheniformis ATHE9 and Bacillus Mojavensis ATHE13 as Newly Strains Isolated from Oil-Contaminated Soil. Journal of Geography, Environment and Earth Science International, 11(2): 1-11.

[17] Shayannejad M, Ostad-Ali-Askari K, Eslamian S, et al. 2017, Development of a new method for determination of infiltration coefficients in furrow irrigation with natural non-uniformity of slope. Sustain. Water Resour. Manag., 3(2): 163-169.

[18] Shojaei N, Shafaei-Bejestan M, Eslamian S, Marani-Barzani M, P. Singh V, Kazemi M, Ostad-Ali-Askari K. 2017, Assessment of Drainage Slope on the Manning Coarseness Coefficient in Mountain Area. International Journal of Constructive Research in Civil Engineering (IJCRCE), 3(1): 33-40.

[19] Bahmanpour H, Awhadi S, Enjili J, Eslamian S, Ostad-Ali-Askari K. 2017, Optimizing Absorbent Bentonite and Evaluation of Contaminants Removal from Petrochemical Industries Wastewater. International Journal of Constructive Research in Civil Engineering (IJCRCE), 3(2): 34-42.

[20] Shayannejad M, Eslamian S, Gandomkar A, Marani-Barzani M, Amoushahi-Khouzani M, Majidifar Z, Rajaei-Rizi F, Kazemi M, P. Singh V, Dehghan SH, Shirvani-Dastgerdi H.R, Norouzi H, Ostad-Ali-Askari K. 2017, A Proper Way to Install Trapezoidal Flumes for Measurements in Furrow Irrigation Systems. International Journal of Research Studies in Agricultural Sciences (IJRSAS), 3(7): 1-5.

[21] DehghanSh, Kamaneh S.A.A., Eslamian S, Gandomkar A, Marani-Barzani M, Amoushahi-Khouzani M, Singh V.P., Ostad-Ali-Askari K. 2017, Changes in Temperature and Precipitation with the Analysis of Geomorphic Basin Chaos in Shiraz, Iran. International Journal of Constructive Research in Civil Engineering (IJCRCE), 3(2): 50-57.

[22] Ostad-Ali-Askari K, Shayannejad M. 2016, FLOOD ROUTING IN RIVERS BY MUSKINGUM'S METHOD WITH NEW ADJUSTED COEFFICIENTS. International Water Technology Journal, IWTJ, 6(3): 189-194.

[23] Ostad-Ali-Askari K, Shayannejad M, Ghorbanizadeh-Kharazi H. 2017, Artificial Neural Network for Modeling Nitrate Pollution of Groundwater in Marginal Area of Zayandeh-rood River, Isfahan, Iran. KSCE Journal of Civil Engineering, 21(1):134-140. Korean Society of Civil Engineers. DOI 10.1007/s12205-016-0572-8.

[24] Shayannejad M, Ostad-Ali-Askari K, Ramesh A, Singh V.P., Eslamian S. 2017, Wastewater and Magnetized Wastewater Effects on Soil Erosion in Furrow Irrigation. International Journal of Research Studies in Agricultural Sciences (IJRSAS), 3(8): 1-14. http://dx.doi.org/10.20431/2454-6224.0308001.

[25] Shayannejad M, Soltani-Toudeshki A.R, Arab M.A, Eslamian S, Amoushahi-Khouzani M, MaraniBarzani M, Ostad-Ali-Askari K. 2017, A Simple Method for Land Grading Computations and its Comparison with Genetic Algorithm (GA) Method. International Journal of Research Studies in Agricultural Sciences (IJRSAS), 3(8): 26-38.

[26] Mohieyimen P, Eslamian S, Ostad-Ali-Askari K, Soltani M. 2017,Climate Variability: Integration of Renewable Energy into Present and Future Energy Systems in Designing Residential Buildings. International journal of Rural Development, Environment and Health Research(IJREH), 1(2): 18-30.

[27] Shayannejad M, Ostad-Ali-Askari K, Eslamian S, et al. 2017, Flow Hydraulic Investigation of the Wastewater on the Soil and Magnetic Field Effects in This Field. International Journal of Constructive Research in Civil Engineering (IJCRCE), 3(3): 1-15. 
[28] Shayannejad M, Eslamian S, Singh V.P., Ostad-Ali-Askari K, et al. 2017, Evaluation of Groundwater Quality for Industrial Using GIS in Mountainous Region of Isfahan Province, Koh-Payeh, Isfahan, Iran. International Journal of Constructive Research in Civil Engineering (IJCRCE), 3(3): 24-37.

[29] Eslamian S, P. Singh V, Ostad-Ali-Askari K, R. Dalezios N, Yihdego Y, et al. 2017, Assessment of Aridity Using Geographical Information System in Zayandeh-Roud Basin, Isfahan, Iran. International Journal of Mining Science (IJMS), 3(2): 49-61.

[30] Askari Z, Samadi-Boroujeni H, Fattahi-Nafchi R, Yousefi N, Eslamian S, Ostad-Ali-Askari K, P. Singh V, R. Dalezios N. 2017, Prediction Comparison of Flow Resistance in Channels with Rounded and Angular Coarse Rough Beds. American Research Journal of Civil And Structural, 3(1): 1-15.

[31] Ghane M, Alvankar S.R., Eslamian S, Amoushahi-Khouzani M, Gandomkar A, Zamani E, Marani-Barzani M, Kazemi M, Soltani M, Dehghan SH, P. Singh V, Ostad-Ali-Askari K, HaeriHamedani M, ShirvaniDastgerdi H.R., Zalaki-Badil N. 2017, Sensitivity Analysis of Runoff Model by SWAT to Meteorological Parameters: A Case Study of Kasillian Watershed, Mazandaran, Iran. International Journal of Research Studies in Agricultural Sciences (IJRSAS), 3(10): 1-20.

[32] Shayannejad M, Abedi M.S., Eslamian S, Ostad-AliAskari K, Gandomkar A, Cheng A, et al. 2017, The Contribution of Artificial Charging in Optimal Exploitation of Water Resources, Isfahan, Iran. InternationalJournal of Mining Science (IJMS), 3(3): 9-20.

[33] Eslamian S,Ostad-AliAskari K, et al. 2017, Guidelines to Optimal Design of Furrow Irrigation Based on Plants, Soil and Furrow Specifications. International Journal of Constructive Research in Civil Engineering (IJCRCE), 3(4): 20-39.

[34] Eslamian S, Gandomkar A, Khademolhoseiny A, Ostad-Ali Askari K, et al. 2017, The Study on the GeoMorphism Related Characteristics of Shiraz Geomorphic Basin, Fars Province, Iran. International Journal of Mining Science (IJMS), 3(4): 10-23. DOI: http://dx.doi.org/10.20431/2454-9460.0304002

[35] Boogaard, F. and Eslamian, S., 2015, Water Reuse and Sustainable Urban Drainage Systems, in Urban Water Reuse Handbook, Ch. 4, Ed. By Eslamian, S., Taylor and Francis, CRC Group, USA, 37-44.

[36] Banihabib, M. E., Zahraei, A. and Eslamian, S., 2016. Dynamic Programming Model for the System of a Non- Uniform Deficit Irrigation and a Reservoir. Irrigation and Drainage, Vol. 66, No. 1, 71-81

[37] Esmailzadeh, M., Heidarpour, M., Eslamian, S. , 2015, Flow characteristics of sharp-crested side sluice gate, ASCE's Journal of Irrigation and Drainage Engineering, Vol. 141, No. 7, 10.1061/(ASCE)IR.19434774.0000852.

[38] Salarian, M., Najafi, M., Davari, K., Eslamiyan, S. S., Heidari, M., 2014, The most Appropriate Method to Estimate Potential Evapotranspiration in Meteorological Data Scarce Condition in the Warm and Cold Months of the Year (Case Study of Isfahan), Iranian Journal of irrigation and Drainage, No. 1, Vol. 8, 6273.

[39] Taheri-Soderjani, H. and Eslamian, S. S., 2016, Determining Evapotranpiration using the GIS and cluster analysis in Isfahan Province, Iran, The Second National Congress on Irrigation and Drainage, August 2325, Isfahan, Iran.

[40] Ansari, S., Eslamian, S. S., Pourabdullah, N., 2016, The effect of Meteorological Parameters on Rainfed Wheat and Barely Yield in Chahrmahal-Bakhteyari Province, The Second National Congress on Irrigation and Drainage, August 23-25, Isfahan, Iran.

[41] Pourabdullah, N., Eslamian, S. S., Ansari, S., 2016, Comparsison of the different equations of evapotranspiration estimation in Chahrmahal-Bakhteyari Province, The Second National Congress on Irrigation and Drainage, August 23-25, Isfahan, Iran.

[42] Hasheminejad, S. Y., Eslamian, S. S., 2016, The effect of the PET solution methods on RDI Drought Index, The Second National Congress on Irrigation and Drainage, August 23-25, Isfahan, Iran.

[43] The application of Artificial Neural Network and ArcGIS in groundwater rable simulation of Mahyar plain. Isfahan Province, The Second National Congress on Irrigation and Drainage, August 23-25, Isfahan, Iran.

[44] Rahimian, M. H., Shayannejad, M., Eslamian, S., Gheysari, M., Taghvaeian, S., Jafari, R., The quantative and qualitative evaluation of available water for irrigating pistachios gardens in saline conditions (Case study: Ardekan, Yazd Province), The Second National Congress on Irrigation and Drainage, August 23-25, Isfahan, Iran.

[45] Fakhri, M, Farzaneh, M. R., Eslamian, S. S., Malbusi, S., 2011, Uncertainty analysis of statistical downscaling to predict dry and wet spell, 3th National Conference on Irrigation and Drainage network, Birjand, Iran.

[46] Farzaneh, M. R., Samadi, S. Z., Akbarpour, A., Eslamian, S. S., 2010, Evaluation of increasing trend of temperature in the period 2040 to 2069 in Karoon Catchment, 4th National Conference on World Environment Day, Tehran, Iran. 
[47] Eslamian, S. S., Farzaneh, M. R., Hasanzadeh, H., Akbarpur, A., 2010, Wind frequency analysis in Birjand region for electrical power plant construction, 1th National Conference on Renewable energy, Birjand, Iran.

[48] Abedi-Koupai J., Eslamian S., Gohari A., 2009, Study the Use of Bamboo Nano-Particles to Improve the Engineering Properties of Hydraulic Structural, The 3rd Conference on Construction Experiences of the Hydraulic Constructions and Irrigation and Drainage Network, Tehran University, Iran.

[49] Eslamian, S., Gohari A., M. J. Zareian, 2006, Study the Benefits and Problems of the Use of Prefabricated Channels in the Irrigation Network of Isfahan, The Second Conference on Construction Experiences of the Hydraulic Constructions and Irrigation and Drainage Network, Tehran University, Iran.

[50] Osroosh, Y., Mostafazadeh, B. and S. Eslamian, 2005, Automatic water advance recorder for surface irrigation. Proceedings of the Workshop on Mechanized Surface Irrigation, Iranian National Committee on Irrigation and Drainage (IRNCID), Karaj, Iran.

[51] Mostafazadeh, B., Ataie, M. and S. S. Eslamian,1999, The evaluation of trickle irrigation systems in Isfahan province and investigating the possibility of improvement. The 9th National Irrigation and Drainage Seminar, 24-25 Feb., Tehran, Iran.

[52] Coles, N. A. and Eslamian, S., 2017, Definition of Drought, Ch. 1 in Handbook of Drought and Water Scarcity, Vol. 1: Principles of Drought and Water Scarcity, Ed. by Eslamian S. and Eslamian F., Francis and Taylor, CRC Press, USA, 1-12.

[53] Dalezios, N. R., Dunkel, Z., Eslamian, S., 2017, Meteorological Drought Indices: Definitions, Ch. 3 in Handbook of Drought and Water Scarcity, Vol. 1: Principles of Drought and Water Scarcity, Ed. by Eslamian S. and Eslamian F., Francis and Taylor, CRC Press, USA, 24-44.

[54] Goyal, M. K. Gupta, V., Eslamian, S., 2017, Hydrological Drought: Water Surface and Duration Curve Indices, Ch. 4 in Handbook of Drought and Water Scarcity, Vol. 1: Principles of Drought and Water Scarcity, Ed. by Eslamian S. and Eslamian F., Francis and Taylor, CRC Press, USA, 45-72.

[55] Dalezios, N. R., Gobin, A., Tarquis Alfonso, A. M., and Eslamian, S., 2017, Agricultural Drought Indices: Combining Crop, Climate, and Soil Factors, Ch. 5 in Handbook of Drought and Water Scarcity, Vol. 1: Principles of Drought and Water Scarcity, Ed. by Eslamian S. and Eslamian F., Francis and Taylor, CRC Press, USA, 73-90.

[56] TishehZan, P. and Eslamian, S., 2017, Agricultural Drought: Organizational Perspectives, Ch. 6 in Handbook of Drought and Water Scarcity, Vol. 1: Principles of Drought and Water Scarcity, Ed. by Eslamian S. and Eslamian F., Francis and Taylor, CRC Press, USA, 91-108.

[57] Bazrkar, M. H., Eslamian, S., 2017, Ocean Oscillation and Drought Indices: Application, Ch. 8 in Handbook of Drought and Water Scarcity, Vol. 1: Principles of Drought and Water Scarcity, Ed. by Eslamian S. and Eslamian F., Francis and Taylor, CRC Press, USA, 127-136.

[58] Basu, R., Singh, C. K., Eslamian, S., 2017, Cause and Occurrence of Drought, Ch. 9 in Handbook of Drought and Water Scarcity, Vol. 1: Principles of Drought and Water Scarcity, Ed. by Eslamian S. and Eslamian F., Francis and Taylor, CRC Press, USA, 137-148.

[59] Bazrafshan, J., Hejabi, S., Eslamian, S., 2017, Drought Modeling Examples, Ch. 11 in Handbook of Drought and Water Scarcity, Vol. 1: Principles of Drought and Water Scarcity, Ed. by Eslamian S. and Eslamian F., Francis and Taylor, CRC Press, USA, 167-188.

[60] Jonathan Peter Cox, Sara ShaeriKarimi, Eslamian, S., 2017, Real-Time Drought Management, Ch. 13 in Handbook of Drought and Water Scarcity, Vol. 1: Principles of Drought and Water Scarcity, Ed. by Eslamian S. and Eslamian F., Francis and Taylor, CRC Press, USA, 209-216.

[61] Garg, V. and Eslamian, S., 2017, Monitoring, Assessment, and Forecasting of Drought Using Remote Sensing and the Geographical Information System. Ch. 14 in Handbook of Drought and Water Scarcity, Vol. 1: Principles of Drought and Water Scarcity, Ed. by Eslamian S. and Eslamian F., Francis and Taylor, CRC Press, USA, 217-252.

[62] Dalezios, N. R., Tarquis Alfonso, A. M., and Eslamian, S., 2017, Drought Assessment and Risk Analysis, Ch. 18 in Handbook of Drought and Water Scarcity, Vol. 1: Principles of Drought and Water Scarcity, Ed. by Eslamian S. and Eslamian F., Francis and Taylor, CRC Press, USA, 323-344.

[63] Dalezios, N. R., Spyropoulosand, N. V., Eslamian, S., 2017, Remote Sensing in Drought Quantification and Assessment, Ch. 21 in Handbook of Drought and Water Scarcity, Vol. 1: Principles of Drought and Water Scarcity, Ed. by Eslamian S. and Eslamian F., Francis and Taylor, CRC Press, USA, 377-396.

[64] Araghinejad, S., Hosseini-Moghari, S. M., Eslamian, S., 2017, Application of Data-Driven Models in Drought Forecasting, Ch. 23 in Handbook of Drought and Water Scarcity, Vol. 1: Principles of Drought and Water Scarcity, Ed. by Eslamian S. and Eslamian F., Francis and Taylor, CRC Press, USA, 423-440. 
Multi-Variable Location Assessment for Building Modified Stone-Concrete Dams in the Drainage Basin of Golpayegan Through Fuzzy Logic and Boolean Method, Isfahan, Iran

[65] Vafakhah, M., and Eslamian, S., 2017, Application of Intelligent Technology in Rainfall Analysis, Ch. 24 in Handbook of Drought and Water Scarcity, Vol. 1: Principles of Drought and Water Scarcity, Ed. by Eslamian S. and Eslamian F., Francis and Taylor, CRC Press, USA, 441-460.

[66] Vafakhah, M., Akbari Majdar, H. and Eslamian, S., 2017, Rainfall Prediction Using Time Series Analysis, Ch. 28 in Handbook of Drought and Water Scarcity, Vol. 1: Principles of Drought and Water Scarcity, Ed. by Eslamian S. and Eslamian F., Francis and Taylor, CRC Press, USA, 517-540.

[67] González, M. H., Garbarini, E. M., Rolla, A. L., and Eslamian, S., 2017, Meteorological Drought Indices: Rainfall Prediction in Argentina, Ch. 29 in Handbook of Drought and Water Scarcity, Vol. 1: Principles of Drought and Water Scarcity, Ed. by Eslamian S. and Eslamian F., Francis and Taylor, CRC Press, USA, 541-570.

[68] Hadizadeh, R. and Eslamian, S., 2017, Modeling Hydrological Process by ARIMA-GARCH Time Series, Ch. 30 in Handbook of Drought and Water Scarcity, Vol. 1: Principles of Drought and Water Scarcity, Ed. by Eslamian S. and Eslamian F., Francis and Taylor, CRC Press, USA, 571-590.

[69] Mujere, N., Yang, X. and Eslamian, S., 2017, Gradation of Drought-Prone Area, Ch. 31 in Handbook of Drought and Water Scarcity, Vol. 1: Principles of Drought and Water Scarcity, Ed. by Eslamian S. and Eslamian F., Francis and Taylor, CRC Press, USA, 591-606.

[70] MahmudulHaque, M., Amir Ahmed, A., Rahman, A., Eslamian, S., 2017, Drought Losses to Local Economy, Ch. 33 in Handbook of Drought and Water Scarcity, Vol. 1: Principles of Drought and Water Scarcity, Ed. by Eslamian S. and Eslamian F., Francis and Taylor, CRC Press, USA, 627-642.

[71] Fakhruddin, B. S. H. M., Eslamian, S., 2017, Analysis of Drought Factors Affecting the Economy, Ch. 34 in Handbook of Drought and Water Scarcity, Vol. 1: Principles of Drought and Water Scarcity, Ed. by Eslamian S. and Eslamian F., Francis and Taylor, CRC Press, USA, 643-656.

[72] Dalezios, N. R., Eslamian, S., 2017, Environmental Impacts of Drought on Desertification Classification, Ch. 3 in Handbook of Drought and Water Scarcity, Vol. 2: Environmental Impacts and Analysis of Drought and Water Scarcity, Ed. by Eslamian S. and Eslamian F., Francis and Taylor, CRC Press, USA, 45-64.

[73] Nazif, S. and Tavakolifar, H., Eslamian, S., 2017, Climate Change Impact on Urban Water Deficit, Ch. 5 in Handbook of Drought and Water Scarcity, Vol. 2: Environmental Impacts and Analysis of Drought and Water Scarcity, Ed. by Eslamian S. and Eslamian F., Francis and Taylor, CRC Press, USA, 81-106.

[74] Shahid, S., Alamgir, M., Wang, X.-J., Eslamian, S., 2017, Climate Change Impacts on and Adaptation to Groundwater, Ch. 6 in Handbook of Drought and Water Scarcity, Vol. 2: Environmental Impacts and Analysis of Drought and Water Scarcity, Ed. by Eslamian S. and Eslamian F., Francis and Taylor, CRC Press, USA, 107-124.

[75] Orimoogunje, O. O. I., Eslamian, S., 2017, Minimizing the Impacts of Drought, Ch. 8 in Handbook of Drought and Water Scarcity, Vol. 2: Environmental Impacts and Analysis of Drought and Water Scarcity, Ed. by Eslamian S. and Eslamian F., Francis and Taylor, CRC Press, USA, 143-162.

[76] Maleksaeidi, H., Keshavarz, M., Karami, E., Eslamian, S., 2017, Climate Change and Drought: Building Resilience for an Unpredictable Future, Ch. 9 in Handbook of Drought and Water Scarcity, Vol. 2: Environmental Impacts and Analysis of Drought and Water Scarcity, Ed. by Eslamian S. and Eslamian F., Francis and Taylor, CRC Press, USA, 163-186.

[77] Reyhani, M. N., Eslamian, S., Davari, A., 2017, Sustainable Agriculture: Building Social-Ecological Resilience, Ch. 10 in Handbook of Drought and Water Scarcity, Vol. 2: Environmental Impacts and Analysis of Drought and Water Scarcity, Ed. by Eslamian S. and Eslamian F., Francis and Taylor, CRC Press, USA, $187-204$.

[78] Crusberg, T. C., Eslamian, S., 2017, Drought and Water Quality, Ch. 11 in Handbook of Drought and Water Scarcity, Vol. 2: Environmental Impacts and Analysis of Drought and Water Scarcity, Ed. by Eslamian S. and Eslamian F., Francis and Taylor, CRC Press, USA, 205-218.

[79] Gaaloul, N., Eslamian, S., and Laignel, B., 2017, Contamination of Groundwater in Arid and Semiarid Lands, Ch. 16 in Handbook of Drought and Water Scarcity, Vol. 2: Environmental Impacts and Analysis of Drought and Water Scarcity, Ed. by Eslamian S. and Eslamian F., Francis and Taylor, CRC Press, USA, 291-314.

[80] Banjoko, B., Eslamian, S., 2017, Sanitation in Drought, Ch. 17 in Handbook of Drought and Water Scarcity, Vol. 2: Environmental Impacts and Analysis of Drought and Water Scarcity, Ed. by Eslamian S. and Eslamian F., Francis and Taylor, CRC Press, USA, 315-330.

[81] Davari, A., Bagheri, A., Reyhani, M. N., Eslamian, S., 2017, Environmental Flows Assessment in Scarce Water Resources, Ch. 18 in Handbook of Drought and Water Scarcity, Vol. 2: Environmental Impacts and Analysis of Drought and Water Scarcity, Ed. by Eslamian S. and Eslamian F., Francis and Taylor, CRC Press, USA, 331-352. 
[82] Qian, Q., Eslamian, S., 2017, Streamflow Quality in Low-Flow Conditions, Ch. 20 in Handbook of Drought and Water Scarcity, Vol. 2: Environmental Impacts and Analysis of Drought and Water Scarcity, Ed. by Eslamian S. and Eslamian F., Francis and Taylor, CRC Press, USA, 375-386.

[83] MohammadzadeMiyab, N., Eslamian, S., Dalezios, N. R., 2017, River Sediment in Low Flow Condition, Ch. 21 in Handbook of Drought and Water Scarcity, Vol. 2: Environmental Impacts and Analysis of Drought and Water Scarcity, Ed. by Eslamian S. and Eslamian F., Francis and Taylor, CRC Press, USA, 387-408.

[84] Pérez-Blanco, C. D., Delacámara., G., Gómez., C. M., Eslamian, S., 2017, Crop Insurance in Drought Conditions, Ch. 23 in Handbook of Drought and Water Scarcity, Vol. 2: Environmental Impacts and Analysis of Drought and Water Scarcity, Ed. by Eslamian S. and Eslamian F., Francis and Taylor, CRC Press, USA, 423-444.

[85] Kahrizi, D., Esfahani, K., Ashraf Mehrabi, A., Ghaheri, M., Azizi Aram, Z., Khosravi, S., Eslamian, S., 2017, Biotechnology for Drought Improvement, Ch. 24 in Handbook of Drought and Water Scarcity, Vol. 2: Environmental Impacts and Analysis of Drought and Water Scarcity, Ed. by Eslamian S. and Eslamian F., Francis and Taylor, CRC Press, USA, 445-460.

[86] Wade, P., Eslamian, S., 2017, Water Issues from a System Dynamics Perspective, Ch. 25 in Handbook of Drought and Water Scarcity, Vol. 2: Environmental Impacts and Analysis of Drought and Water Scarcity, Ed. by Eslamian S. and Eslamian F., Francis and Taylor, CRC Press, USA, 461-488.

[87] Rahman, A., Hajani, E., Eslamian, S., 2017, Rainwater Harvesting in Arid Regions of Australia, Ch. 26 in Handbook of Drought and Water Scarcity, Vol. 2: Environmental Impacts and Analysis of Drought and Water Scarcity, Ed. by Eslamian S. and Eslamian F., Francis and Taylor, CRC Press, USA, 489-500.

[88] Mukherjee, S., Yadav, K., Eslamian, S., 2017, Soil Contaminations in Arid and Semiarid Land, Ch. 29 in Handbook of Drought and Water Scarcity, Vol. 2: Environmental Impacts and Analysis of Drought and Water Scarcity, Ed. by Eslamian S. and Eslamian F., Francis and Taylor, CRC Press, USA, 547-556.

[89] Dayani, S., Sabzalian, M. R., Hadipour, M. Eslamian, S., 2017, Water Scarcity and Sustainable Urban Green Landscape, Ch. 30 in Handbook of Drought and Water Scarcity, Vol. 2: Environmental Impacts and Analysis of Drought and Water Scarcity, Ed. by Eslamian S. and Eslamian F., Francis and Taylor, CRC Press, USA, 557-604.

[90] Gohari, A., Zareian, M. J., Eslamian, S., Nazari, R. 2017, Interbasin Transfers of Water: Zayandeh-Rud River Basin, Ch. 32 in Handbook of Drought and Water Scarcity, Vol. 2: Environmental Impacts and Analysis of Drought and Water Scarcity, Ed. by Eslamian S. and Eslamian F., Francis and Taylor, CRC Press, USA, 619-630.

[91] Banjoko, B., Eslamian, S., 2017, Environmental Evaluation: Lessons Learned from Case Studies, Ch. 33 in Handbook of Drought and Water Scarcity, Vol. 2: Environmental Impacts and Analysis of Drought and Water Scarcity, Ed. by Eslamian S. and Eslamian F., Francis and Taylor, CRC Press, USA, 631-664.

Citation: Dr. Kaveh Ostad-Ali-Askari et.al. (2017) Multi-Variable Location Assessment for Building Modified Stone-Concrete Dams in the Drainage Basin of Golpayegan Through Fuzzy Logic and Boolean Method, Isfahan, Iran, International Journal of Constructive Research in Civil Engineering, 3(4), pp.81-91. DOI: http://dx.doi. org/10.20431/2454-8693.0304008

Copyright: () 2017 Dr. Kaveh Ostad-Ali-Askari, This is an open-access article distributed under the terms of the Creative Commons Attribution License, which permits unrestricted use, distribution, and reproduction in any medium, provided the original author and source are credited. 